\title{
The Trend of Development and Functions of Mathematic Contemplation in Elementary School Boys
}

\author{
Mamatov M.SH., ${ }^{1}$ Karimova K.R. ${ }^{2}$ \\ ${ }^{1,2}$ National University of Uzbekistan
}

\begin{abstract}
Here given the features, characteristic qualities of mathematic thinking and possibilities of increasing it during teaching mathematics in primary classes relatively to the formation of separate forms of mathematical thinking from the methods of teaching the mathematics, methods of scientific thinking.

Key words: mathematical thinking, synthesis, induction, deduction, abstraction, logical thinking, abstract thinking.
\end{abstract}

Article Received: 16th October, 2020; Article Revised: 30th December, 2020; Article Accepted: 08th January, 2021

\section{Entrance}

Elementary school is the fundament and next education of child is connected with it. This makes a separate responsibility in teachers of primary school. Teaching the reading and writing is not the only duty of teachers but teaching the spiritual thoughts, increasing their excellent possibilities and the effective ways of teaching too. The next education is the most important in the world with full of information. Teaching children in working with information and teaching identifying the most important one is important.

It is identifies the formation of the duty of "teaching the reading" plays a great role in developing the mathematic thinking in State Education Standard. There mentioned, the pupils develop the mathematic thinking, makes the mathematic thinking, pupil learn using the mathematic knowledge in solving the mathematical exercises and develops the mathematical sense in the result of studying of "Mathematics".

The feature of mathematics makes the effect in developing the thought, because the developing the thinking is connects with the analyzing the methods of thinking, generalizing, abstract and the formation of methods of scientific knowledges. By the thought of experts, any subject cannot compete with mathematics in developing the individual thinking.

The famous psychologist J.V.Piaje says, the logics is the only and the main measure of thinking and developing the logistic thinking is basis in mathematic thinking. He considers the development of kid's thinking is the biological process of development of brain system. The mental development is biological maturity as Piaje says.

By the meaning of D.J.Ikramov the mathematic thinking is connected with the complex of logical exercises. Analyzing the different ideas and comparing them shows the mathematic thinking is activity of pupil in learning among the surrounded world objects and accidents besides that the mathematic rules.

The development of mathematic thinking is connected with the amount of learning the mathematics. The famous psychologist L.M.Fridman says, "the mathematic thinking is not connected with the abstract and object but it may be define by taking into account the saving of mutual laws between them" [4].

\section{Making exercises.}

Increasing the mathematical thinking is connected with the formation of abilities of ideological thinking of solving the mathematical exercises, using of the mathematical symbols, laws and expressions. Besides that, it is partly 
mentioned the opportunity of complexing and systematizing the mathematical materials, building and separating the mathematic models of life situations.

It is organized the formation the several features of mathematical thought in the pupil by teaching the mathematics such as proper choosing the ideological sequence in the process of solving the problematic exercises, the accuracy and consistency of the problem-solving sequence, brevity of conclusions, accurate and complete statement of opinion.

The existence of a clear and rigidly structured logical thinking scheme is one of the main features of mathematical thought, because the partial loss of consistency in a single step of the thinking sequence also results in a complete lack of proof of the expected outcome or a chance to solve the problem

In addition to the rigidity of reason to be a mathematical thinker, clarity and brevity of explanations are also characteristic. Mathematical working cannot tolerate superfluous words, distracting ideas.Therefore, mathematic textbooks are given to pupils in a concise form with as much skills as possible and with great skill without unnecessary elements of thinking.

From the above considerations it can be understood that the development of such an educational process will be very insignificant if targeted work on the formation of methods of mental activity is not carried out. If targeted work is done to develop ways of thinking, the results of knowledge acquisition by pupils will be higher.

Inductive and deductive methods are common in the teaching of mathematics. According to these methods, clear and abstract forms of thinking, which are the main components of mathematical thinking, are formed. Clear thinking of pupils is formed and developed in the interaction with certain models, that is, in the process of working with certain objects.Specific thinking is important in shaping the characteristic abstract concepts of mathematical thinking. While teaching mathematics, certain thinking is important in the primary classes. In order to develop this type of thinking, it is expedient to teach pupils generalization methods in primary and middle grades, i.e. to teach them to form general ideas from specificity.It should be borne in mind that the development of certain thinking in pupils, the constant reference to visual ideas can slow down the development of abstract thinking. They believe that the development of mathematical thinking in the primary grades is not always given enough attention and that all the necessary thinking skills develop independently with age.Such a misconception leads to a slowdown in the growth of children's mathematical thinking, and as a result, their intellectual abilities provide a reason to get the expected result for their individual development in the future.In the middle classes, the role of explicit thinking gradually diminishes, and instead of explicit thinking, abstract thinking develops as its generalization.

Abstract thinking is formed in parallel with mental operation. Through abstraction, some features of the object are distracted, but more basic, distinctive features are emphasized.In elementary classes, abstraction occurs in teaching the solution of equations, because the basic, important features of the examples studied are the basis for identifying the unknowns.Thus, abstract thinking is distinguished by the conscious distraction from the content of a particular object and the use of its general properties.

The first-class has a visualfigurative mind, his analytical ability is elementary, and the content of generalizations and concepts is viewed only superficially and often insignificantly.

Visual-practical thinking is the first type of thinking to emerge in early childhood.If the child begins to work with emotional images, then he develops the second type of visual-figurative thinking. 
And only in the process of schooling does the child begin to develop intelligence, verbal and logical thinking. Verbal-logical thinking is formed by thinking actions (analysis, synthesis, comparison, generalization, etc.). The results of mental action are then manifested in the form of judgment - by affirming or denying what is related to the object of thought.

According to the definition of the generality of judgments in relation to the object, it forms the necessary and sufficient number of decisions on the most important features. One of the most important actions of judgments in mathematics is the conclusion that one or more and in a certain way related decisions, the result of which is known to us, is a new judgment containing new knowledge. When it comes to the development of thinking in the process of teaching mathematics, mathematical thinking is usually meant.

The mathematician A.Y.Xinchin who made a lot in mathematics shows the four feature of mathematical thinking:

1) "logical structure of thinking has been brought to the norm of superiority";

2) "expression an idea concisely, succinctly, conscious aspiration always finds the shortest logical way to a given goal";

3) "evidence presented is clearly broken down into pieces";

4) "the accuracy of the designation is extremely high".

Undoubtedly, as A.Y,Xinchin mentions that the qualities of mathematical thinking are more important and unique than those listed above, but they mainly reflect the external features of the mathematical way of thinking.In math classes, children enjoy playing interactive games.Using such methods, the teacher prepares mathematical thinkers for life by stamping the topics in the child's memory.

\section{Main results.}

Through the analysis of the following issues we can clearly see that the focus is on the formation of the four important features of mathematical thinking. Questions 1-3 can be used in grade 4 to determine how well they have mastered these topics once pupils have learned to add numbers in column form.

1-exercise.The numbers $1,2,3,4$, $5,6,7,8,9$ are written on the board, and two pupils are playing the game as follows. The first beginner selects one of these numbers and declares, for example, 9, 9-nine. The second continuous pupil also chooses one of these numbers, for example, 9, and adds 9 to the number declared by the first pupil, that is, $9+9=$ 18 and 18 is eighteen. Now the first pupil chooses one of these numbers, for example 5 , and the second pupil adds it to the number he has declared, that is, 18 , declares that $18+5=23$ and 23 is twentythree, and so on. Whoever announces the number 85 first is considered the winner.

Question: 1) Who wins in this game, the first beginner or the second continuing pupil?

2) If the first person in the game to announce the number 80 is said to be the winner, which pupil will win, the first pupil or the second pupil?

Proof your answer.

If the player who says 85 wins in this game, it will only be the first pupil if he or she can consciously determine the logical path leading to the given goal by directing the thought correctly. We will consider 2 existing cases of problem solving.

1-situation. The shortest way in solution the exercise consists of 11 ways. In this case, both pupils say only the number 94 times, and the second pupil announces the final result 72 .The first pupil thinks as follows in ninth step:

"If I say a number greater than 3, the sum is at least 76 , and my opponent wins by choosing 9 or one of the numbers given to him according to the sum". If I 
choose 1 or 2 , my opponent chooses 2 or 1 numbers according to these numbers and the sum is 75 . As a result, no matter which number I say, my opponent wins by saying that he completes the number I said by 10 . If I say 3, the sum is 75 , and even if my opponent says an arbitrary number, I win by saying its complement to 10 . And the first reader consciously directs his mind clearly and correctly, chooses the number 3 and declares 75 . In step 10, the second pupil says an arbitrary number. In step 11 , the first pupil declares 85 by adding 10 to the number said by the second pupil and wins.

2-situation.The game ends in 17 steps in this case.

Let's imagine that there are A and $\mathrm{V}$ pupils and A pupil won the game. The $\mathrm{A}$ pupil should say 75 in fifteenth step for saying 85 in seventeenth step. Because, Because, if pupil $\mathrm{V}$ says the number 1, pupil A says only the number 9, in other cases, pupil $\mathrm{V}$ says the complement to the number 10 (Pupil A can find 10 fillers at each step). In order for him to say 75 in step 15 , he must have said 65 in step 13 . Because, just as before, if pupil $\mathrm{V}$ says the number 1, pupil A says only 9, in other cases, pupil $\mathrm{V}$ says the complement of the number 10 , and the difference between the steps of pupil A becomes 10. Continuing in the same way, he can say 55 in step 11, 45 in step 9, 35 in step 7, 25 in step 5, 15 in step 3, and 5 in step 1. So, pupil A starts the game with the first 5 numbers and wins.

Now there may be a question. Can pupil 1 make the difference between steps greater than 10 ?

Given that the smallest number that a 2 nd pupil can say is 1 , a 1 st pupil can increase the difference between steps by at least 10. If at any step the difference exceeds 10 , it misses the chance to win; it will not achieve the expected result with a partial loss of consistency in one step of the thinking sequence. That is, the numbers ending in 5 that the first pupil generates are won by the second pupil, who wins by saying 85 in the last step.

From the above, we can conclude that the first pupil to say the last number of a non-multiple of 10 , which must be said at the finish, and the difference between the steps to be 10 , wins. If the finish is a multiple of 10, the first pupil will not be able to say the number 0 according to the condition of the problem, so the winner will be the second pupil.

We ca answer as following for asked exercise:

Answer: 1) The first beginner pupil wins in this game.

2) If, under the conditions of the game, the first pupil to declare the number 80 is said to be the winner, the second pupil to continue wins.

2-exercises. The teacher invited a pupil to the board at will and told him to write an arbitrary three-digit number. The pupil wrote the number 567 on the board, for example. The teacher wrote another three-digit number under this three-digit number, for example 432. Then, he invited another pupil to the board, who also wrote another three-digit number under the two three-digit numbers written on the board. The teacher very quickly counted and wrote the sum of these three three-digit numbers written on the board. "You saw it and you counted," the pupils told the teacher. The teacher now invited another pupil to look at the board and he wrote the six-digit number 632541 on the board. The teacher then wrote the six-digit number 367458 under it. Then another pupil came out and he also wrote 894756 six-digit numbers under the numbers on the board, the teacher calculated the sum very quickly again.

Question: What do you think is the secret to calculating a teacher's sum so quickly?

The super-critical reader identifies the similarities between the results of the first processing and the results of the second processing, focusing on the solutions of the problem (comparative 
practice of thinking). The final result is equal to the number formed by writing the number 1 in front of a number less than one written by the second pupil. So how is this done?

The quick and easy solution to the problem depended on the teacher, who used his opportunity with great skill. He writes a number that fills the room units of

$$
\begin{array}{r}
\left.\begin{array}{r}
567 \\
+432
\end{array}\right\} 999 \\
\frac{785}{1784}
\end{array}
$$

We may ask the following question after teaching the secret of the solution the exercise:

What number should the teacher write so that the result is formed by placing the number 1 in front of the number written by the second pupil?

One of the most important aspects is that the teacher teaches the pupils what is important to define and how to define it in the process of working on the problem. We can see how effective the right choice of designation is in finding solutions to the following issues:

3-exercise.Ali has 4 times less candy than Vali and Ghani has 7 times more candy than Ali. If the total number of candies is 132 , how many candies were in each?

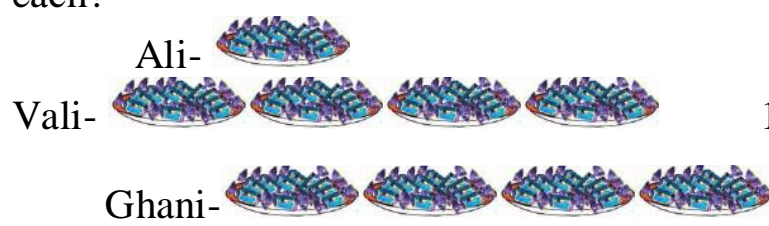

By making such a designation, pupils can find the number of candies in one serving and the number of candies in each pupil using arithmetic operations to determine that Ali has 11, Vali 44, and Ghani 77.

4-exercise. The sum of the distances from Babur and Sabir's homes to school is 970 meters. If Babur walks 30 the number written by the first pupil to 9 . At the result of adding these two numbers will result the largest number of such numbers. For instance, if operations are on three-digit numbers, the result will be 999 . Subtracting 1 from the number written by the second pupil and adding it to 999 gives 1000 , and adding the number reduced by one to 1000 gives the result immediately.

$\begin{array}{r}632541 \\
+367458\end{array}$
\begin{tabular}{c}
894756 \\
\hline 1894755
\end{tabular} 999999

High school pupils can solve this problem without difficulty using the equation $\mathrm{x}+4 \mathrm{x}+7 \mathrm{x}=132$. But elementary school pupils can't find a solution to a complex equation of this kind. So how do you explain the problem to them without drawing an equation? It is important for the teacher to pay attention to the fact that the definitions in the equation are extremely accurate, taking into account the age of the child, systematize the problem and choose the right sequence. He clarified the order which the number of candies of Ali, Vali, and Ghani was increasing with various questions, and suggested that the minimum number of candies be set as one division, including the following designation:

132.

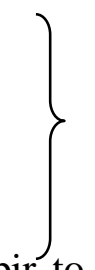

meters longer than Sabir to get to school, find the distance from the school to everyone's home.

This problem can be solved using 2 unknown 2 linear equations. However, let's look at a specific method for elementary grades. In solving this problem, too, the definition must be entered with great skill. We can define the 
distance between pupils 'homes with cuts

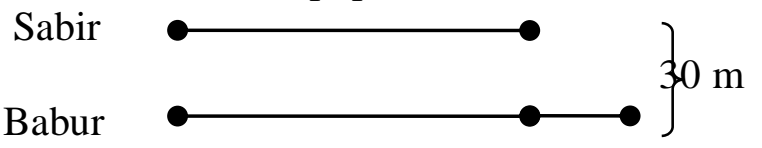

Using the above graphical condition of the problem and the following questions skillfully posed by the teacher, the solution of the problem is much simpler:

1) If the distance from Babur's house to school is equal to the distance from Sabir's house to school, what is the total distance? $(970-30=940$ (meters))

2) What is the distance from Sabir's house to school? (940: 2 $=470$ (meters)

3) What is the distance from Bobur's house to school? $(470+30=500$ (meters)).

Pupils will be able to determine that the houses of Babur and Sabir are located at a distance of 500 meters and 470 meters, respectively, through clear and concise entries.

\section{The discussion of results.}

Nowadays, the mathematical sciences led to the fact that all the qualities of mathematical thinking have their own characteristics. Therefore, the peculiarities of the method of mathematical thinking should be sought not in its widely used methods in other sciences, but in its objects. Mathematical objects have one feature that is free of various materials: these objects are in a certain quantitative, spatial relationship with each other. Mathematics does not study things but it only studies the relationships between things. Therefore, if the relationship between things does not change, it does not matter that these things are replaced by others.

Examples like the one above teach the pupil to summarize the knowledge they have gained and draw general conclusions. The generalization and systematization of the topics covered in such organized lessons forms pupils' mathematical thinking, teaching pupils to approach the as follows:

970 meters

problem creatively, to think independently, using different and shortest methods to solve the problem. Generalization of topics in generalization lessons is one of the didactic ways to develop pupils' mathematical thinking, thinking skills, to determine mathematical concepts and problem statement.

Elementary pupils form clear thinking through visual aids, using visual aids. It is precisely for them that textbooks lack examples and issues to draw general conclusions from specific conclusions to develop pupils' mathematical thinking. The teacher asks the pupil to explain the example and the solution of the problem. Some pupils may be able to solve the problem correctly, but have difficulty explaining how it worked. To help the pupil in such a situation, the teacher should explain by giving an example of solving a problem of similar content. But in some cases this method may not be enough for the pupil to master. In such cases, the teacher should be able to use the systematization method of teaching and use it effectively. It should be noted that the systematization should be as short as possible. This algorithm should act as a plan, a scheme in solving the problem for the reader. The problem-solving system is created by the teacher and teaches the pupil to work on this system. By systematizing the sequence of finding solutions to the problems discussed above, the teacher achieves mastery of the problem by giving pupils problems that are similar in content. The purpose of such lessons is to review the basic concepts of mathematics, to deepen knowledge while teaching to draw general conclusions, and to systematize pupils 'knowledge of mathematics and to form and develop pupils' mathematical thinking through examples and problems. 
In the process of solving a sequence of problems that are the same in content, it helps to identify the shortcomings that pupils could not master in the previous problem, and this allows them to overcome the shortcomings.

In order to develop the mathematical thinking of primary school pupils, it is necessary to teach pupils to correctly master, analyze, compare and generalize each mathematical term and concept from the content, to express their ideas clearly and fluently, to draw conclusions independently. In order to carry out these processes, it is first necessary for pupils to be able to independently compare different types of examples and problems, to find similarities and differences between them and to draw general conclusions.

\section{Conclusion}

In conclusion, the formation of mathematical thinking in primary school involves the ability of pupils to choose the right sequence by systematizing the problem situation, to make the path to the final conclusion clear and concise, and to translate the definitions into the child's language.

Thus, mathematical thinking is a very abstract, theoretical thinking, the objects of which are insignificant and can be interpreted arbitrarily as long as the information between them is preserved.

Teaching and learning is a complex process that primarily involves the activities of the teacher and the learner. Therefore, the teacher not only provides scientific information on the subject, but also plans, organizes, monitors the pupil's learning activities, develops academic work skills, thinking skills and the ability to apply knowledge in practice - all this helps the pupil

\section{References}

1.Andewood Dudley. What Is mathematics for?// Notices of the American Mathematical Society.-2010.- Vol. 57(5). -
P. 601-607.(Андервуд Дудлей. Нимагаматематикани уурганиш керак?//Фан ва турмуш.-Тошкент.2014.-№3-4.-C.31-33.)

2.Пиаже Ж.В. «Речь и мышление ребенка». - Государственное учебнопедагогическое издательство. М.: Римис, 2008. - 448 с.

3.Карабанова О. А. Возрастная психология. Конспект лекций. - 2005.

3.Атаханов Р. Математическое мышление и методика определения уровня его развития / Под ред. В.В. Давыдова. Рига: Эксперимент, 2000. $208 \mathrm{c.}$

3.Гайбуллаев Н.Р. Дырченко И.И. Развитие математических способностей учащихся: Методическое пособие для учителей / Н.P. Гайбуллаев, И.И. Дырченко Т.: Укитувчи, 1988. -248 c.

4.Семаго Н.Я., Семаго М.М. Диагностический альбом для оценки развития познавательной деятельности ребёнка. Дошкольный и младший школьный возраст. М.: Айрис-пресс, 2005.

5.Икрамов Джурабай -Математическая культура школьника [Текст] ... школьников при обучении математике/Дж. Икрамов.-Ташкент :Ўқитувчи, 1981.

6.Коменский Ян Амос. Избранные педагогические сочинения.-М.: Педагогика, 1982.-420c.

7.Маматов М.Ш. Математик таълимда идрок жараёнини ривожлантириш босқичлари// Халқ таълими.Тошкент.2003.-№2.-С.84 -88.

8.Маматов М.Ш. Таълимда кузатиш ва тажриба, индукция ва дедукция// Халқ таьлими.-Тошкент.2003.-№3.-С. 79-81.

9.Матюшкин A.M. Проблемные ситуации в мышлении и обучении. М.: Педагогика, 1972. - 208 с.

10.Хинчин А. Я. О так называемых “задачах на соображение" в курсе арифметики// Матем. просв., cep. 2, 6 (1961), 29-36. 
11.Хинчин А. Я. О воспитательном эффекте уроков математики// Матем. просв., сер. 2, 6 (1961), 7-28.

12. Н. У. Бикбаева, Э. Янгабаева, К. М. Гирфанова. Математика // 4-синф учун дарслик. - Т.: Ўқитувчи, 2017. 